UDC 811.111'272

DOI https://doi.org/10.32838/2663-6069/2020.1-2/13

Duzhyk N. S.

National University of Food Technologies

\title{
EMPLOYING AN ETHICAL APPROACH TO WRITING IN ACADEMIC SETTINGS
}

The paper studies the theoretical underpinning of writing guided by an ethical approach in an academic setting. A particular attention is paid to Sandra Stotsky's framework. Due to its explanatory power, the framework can be applied to students' training in writing fundamentals and ethical thinking. The theoretical value of Stotsky's approach lies in categorizing the writer's responsibilities. They are conceptualized in four categories and represent writing as a manifold intellectual process involving major participants, such as the writer, other writers, and readers. By advancing the idea of academic integrity and providing compelling reasons for avoiding plagiarism, teachers can develop students'respect for academic work and its participants as well as help them avoid ethical problems associated with writing. The framework excludes the social and cultural dimensions of communication and is based on the fundamental academic standards. Examples demonstrate how to apply an ethical approach to composing texts.

Along with the classic rules of academic writing, the paper considers recent approaches to English instruction brought by globalization and technology change. Nowadays youth routinely uses digital technologies and is actively engaged in informal information exchange on social networks where violations of ethical standards are commonplace. This is why reevaluating previous practices and introducing new ones is conducted with respect to the digital environment.

Following the latest trends towards incorporating social issues into the classroom, the paper focuses on methodologies relevant to Ukrainian universities. Although a culturally homogeneous student body is prevailing in Ukraine, the issues of cultural diversity should be introduced in the curriculum due to the growing number of international students and the need to support intercultural exchange.

Unlike cultural diversity, social justice and civic involvement are well represented in English language instruction. Comprehensive guidelines from western research works are a good source for modeling assignments based on Ukrainian realities. An example of this kind is provided in the paper.

Key words: academic writing, English language instruction, ethical approach, plagiarism, inclusiveness.

Problem statement. Nowadays the academic intellectual process is defined by acquiring a wide range of competencies enabling graduates to integrate fully into their professional fields. Writing in foreign languages is a skill broadening personal and professional horizons of those who mastered it.

With the advent of electronic communication, ethical dimensions of writing have regained their relevance and have been conceptualized in a number of frameworks associated with digital environment and greater socializing. Evidently, the students' involvement in writing has overgrown the classroom limits and has found its way to social networks ample with informal and loose rhetoric. Students often emotionally participate in interpersonal exchanges, demean opposing views and shift their criticism from ideas to the opponent's personality.

Social networks are not the only place in which the basic ethical standards are violated. As members of the academic community, students are engaged in intellectual work which includes completing home assignments, carrying out individual and collective projects. Plagiarism is one of the most serious problem regarding students' writing. In the Ukrainian higher education system, this issue is addressed by teaching citation rules, detecting plagiarism in students' assignments with antiplagiarism software and not granting credit for dishonest work. However, a wellstructured comprehensive approach to eliminating plagiarism is yet to be developed. Another problem is unethical misconduct detected in students' writing due to lack of life experience or insufficient training in "moral thinking" and writing fundamentals [7].

The paper objective is to analyze theoretical works on moral implications of writing in academic settings, present different manifestations of unethical conduct in students' works, and offer the tools for overcoming deficiencies in writing. Specific examples 
explain how to avoid ethical lapses and compose inclusive discourses.

Literature review. Sandra Stotsky was one of the scholars who conceptualized writing as moral and civic thinking in the 1990 s $[2 ; 3 ; 4 ; 7]$. Her conceptual framework is categorized in terms of the writer's ethical responsibilities to her readers and is based on the classic cannons of academic writing:

A PROPOSED CATEGORIZATION OF THE ACADEMIC WRITER'S RESPONSIBILITIES

A. With respect to the purposes of academic language

- To define key terms

- To write clearly

B. With respect to other writers

- To consider other writers as intelligent as oneself

- To present another writer's views fairly

- To attribute ideas only to their authors

C. With respect to the integrity of the subject

- To gather all seemingly relevant information on a topic

- To evaluate the relevance and quality of gathered information

- To address all relevant information

- To account for all significant components in an analogy

- To provide adequate evidence for assertions directly or through accessible references

- To use facts accurately

- Not to make blanket generalizations

- Touserepresentative examplesofaphenomenon

- To create texts with no erroneous implications

- To provide correct examples for reasonable generalizations

- To create consistent categories for classifying information

- To create coherent texts

D. With respect to the integrity of the reader

- To assume an open-minded reader

- To use affectively balanced terms

- Not to stereotype possible readers

Four categories of responsibilities are related to a) the purposes of academic language, b) to other writers' works, c) to the integrity of the subject under discussion, and d) to the integrity of the reader. This manifold representation of academic fundamental activities includes major actors of an information exchange, such as the writer, other authors, and readers. By employing Stotsky's framework in academic settings, it seems possible to develop students' respect for the intellectual process and its participants. It also provides guidelines how to avoid ethical problems with writing. Whereas the social and cultural dimensions are excluded from the framework, the general academic principles are employed to improve irresponsible writing. Impartially and unemotionally presented views are in line with the basic academic standards.

Stotsky points out that bad manners and personal insults "are obstacles to academic ways of knowing. They distract the reader's attention from the ideas at the center of academic dialogue and make irrelevant issues appear to be relevant" [7, p. 806]. Civility, displayed in articulate writing and accurate citations, reflects the writer's respect for other writers and readers as well as acknowledges professional dignity. The scholar states that moral virtues can be taught without indoctrinating students.

Friend notes that writing courses at universities have become politically oriented. Composition teachers encourage students to critique dominant ideologies in the society and actively participate in the larger political world $[4$, p. 552]. Classroom activities are designed to involve students in debate about sociocultural tensions and struggles in their own lives. Although students may hold different social values, they are motivated in class to redefine their relationship to the cultural system and widen their moral horizons [6, p. 21]. Meaningful positive and moral change can be brought by exposing students to a greater number of readings, fostering students' self-examination and critique [6, p. 19].

Diversity of the academic community plays an important role in producing knowledge. According to Bizzel, discussion is a major approach to introducing different social views and achieving the general consensus on ethical grounds [1, p. 663]. This approach attempts to value all the different voices that comprise the classroom community. However, when teachers uncover only difference and disagreement and do not show students possibilities for positive alliance with others, it can result in political "quietism" [1, p. 667].

If a university does not serve a diverse population, teachers may choose to expand the classroom participation to real-life interaction with local groups. Such activities provide possibilities for students to encounter diverse others, learn about them, and uncover various perspectives on issues of social importance. Moreover, they tend to expand possibilities for ethical decision-making and social change $[4$, p. 563].

Reflecting on the classroom as a public forum, Elizabeth Ervin considers its potential in fostering students' civic behavior. Raising civic consciousness 
requires not only studying educational materials on popular culture / current issues, but also the models of civic involvement and structured opportunities for participation. In her reconceptualization of the classroom, students are reimagined as citizens, and collaborative learning is a means of commitment to "broader and more diverse publics outside the classroom" [2, p. 395].

Discussion. University students are regularly involved in creating informal discourses. Informal standards of writing can also be observed in an academic setting. From time to time, students send their requests to faculty members or other university employees, expressing their needs too directly or impolitely. Swales and Feak, authors of Academic Writing for Graduate Students, give two examples of ethically flawed messages from students to faculty members.

The first might be considered only a little offensive, the second rather more so. Of course, offending others was not the intention of either writer:

Dear Professor Robinson,

Finally, I can give you something to read. I will leave it in your mailbox soon, so please pick it up when you stop by.

This first message is problematic for two reasons. First, there is the vagueness of soon. (How many times will Professor Robinson have to check her mailbox before she finds [student's] pages?) Second, the end of the message is completely unnecessary. Here is a simple "repair":

Dear Professor Robinson,

Finally, I can give you something to read. I will leave it in your mailbox by noon tomorrow.

Here is the second example.

I am currently working on a paper (approx. $8 / 9$ pages). I should be done on Mon. evening. Could you please go through it $\&$ give your comments by Wed.

This message, according to Swales and Feak, breaks three elements for polite request:

1. Do not impose.

2. Give options.

3. Make the receiver feel good.

Here is what he might have written instead.

I am currently working on a paper (approx. $8 / 9$ pages). I should be done on Mon. evening. If you are not too busy, I would appreciate any comments you might have to make before I submit it. Unfortunately, it is due on Wed., so there isn't much time. If you can help, I'll bring you my draft as soon as it's done. If you can't, that's quite OK too [9, p. 242-243].
Demonstrating to students how to improve inappropriate pieces of writing can broaden their understanding of the academic principles and their use.

In Ukraine, most classes are dominated by a culturally homogeneous student body with minor socioeconomic differences. Their learning styles may vary, but their personal values are mainstream. Like their counterparts all over the world, Ukrainian students are influenced by a global consumer culture in which digital technology plays a central role. Because a number of international students at Ukrainian universities has been steadily growing over the last two decades, raising students' awareness of multicultural issues is a relevant task. It can be achieved by reviewing a broad array of materials on the subject in class and creating courses based on difference.

Modeling civic involvement is an integral part of contemporary writing assignments. It motivates students to acquire some knowledge about the local community, exercise moral judgment, and build an inclusive society.

We have chosen a comprehensive example from Hewings [5, p. 109-110] to demonstrate how tasks are used to raise students' awareness regarding underrepresented groups on the campus, find the ways to connect with others, and improve the quality of someone else's life.

\section{Writing}

At a recent meeting of your college student committee, there was a discussion of fundraising for good causes. Here is an extract from the minutes of the meeting.

5. Any other business

5.1 Daphne Jones noted that college students raised $£ 4,500$ for a number of good causes last year (including Oxfam, UNICEF, people with visual impairment, homeless people), but that the maximum raised for any good cause was only £520. She suggested that next year one particular good cause should be identified, and all funds raised should go to this.

5.2 After discussion it was decided to ask students to write proposals. Students should:

- identify a good cause and say why they would like the college to support it;

- suggest what fundraising activities might be done;

- say what part they will play in the fundraising process.

The college student committee will select the best proposal and choose the student to be in charge of fundraising. 
In the sample answer provided in the book, the choice was made in favor of the United Nations Children's Fund, UNICEF, the aim of which is to ensure that children around the world have access to support, healthcare and education necessary for a happy and healthy childhood [5, p. 243]. In addition to the answer from the key, teachers can use alternative examples to highlight problems of economicallydisadvantaged groups in their country or community.

Here is an example aimed at eliciting an emotional response to difficulties confronting the elderly, at empathizing with representatives of disadvantaged communities, and boosting students' problem-solving skills.

FUNDRAISING FOR HEARING-IMPAIRED PEOPLE: PROPOSAL

\section{Reasons for supporting the hearing impaired}

For next year, I would like to propose fundraising activities to help senior citizens with hearing problems. At a few university events for the local community, I have met some people who were hearing impaired. Some of them suffered from an incurable hearing condition while others were in need of surgery or a hearing aid. From my conversations with senior citizens, I learned that it had been challenging for them to improve their health conditions without some external assistance. Their limited-benefit plans and an insufficient pension had left them in rather a disadvantageous situation. This is why I propose raising money for their needs. I strongly believe that fundraising will bring the university students and the local community closer. It will also enhance the quality of senior citizens' lives.

\section{Fundraising Saturday}

I suggest devoting any Saturday in the spring to fundraising. In the morning, the university might hold two events, such as a garage sale and a bake sale.
Both students and locals can support these events by bringing household items and homemade sweets. Obviously, any participant of fundraising might take pleasure in hunting for bargains or in eating delicious desserts, as well as in contributing to a good cause.

In the afternoon, I would schedule a concert. Along with the college students playing musical instruments and dancing, I would invite local performers to participate in the charity event.

All proceeds from Fundraising Saturday will fund the purchase of hearing aids.

\section{My involvement}

As an organizer of some previous public events at our college, I would like to apply my experience to planning Fundraising Saturday. I may contact the most active and communicative members of the student committee and ask them to arrange both a garage sale and a bake sale. Also I may assist in publishing leaflets about Fundraising Saturday. However, the most rewarding experience for me would be writing a concert scenario and inviting local performers to participate in our charity.

Conclusions. Incorporating an ethical approach into composition classes by western instructors has resulted in productive outcomes which can be used as guidelines for educators from other countries. Conceptualizing writing as a moral responsibility enables a comprehensive and structured eradication of negative practices, such as plagiarism, at university settings.

English language instruction in Ukraine, which was based on the classic cannons until recently, is in need of further improvement. To be in line with the contemporary theories of teaching and gradual change in society, the issues of cultural diversity, social justice, and civic involvement should be included in classroom discussions and writing assignments.

\section{References:}

1. Bizzel P. Beyond Anti-Foundationalism to Rhetorical Authority: 'Cultural Literacy'. College English. 1990. Vol. 52. P. 661-664.

2. Ervin E. Encouraging Civic Participation among First-Year Writing Students; Or, Why CompositionClass Should Be More like a Bowling Team. Rhetoric Review. Spring 1997. Vol. 15. No. 2. P. 382-399.

3. Fornasiero J. and Mrowa-Hopkins C. Explorations and Encounters in French. University of Adelaide Press, 2010. URL: https://www.jstor.org/stable/10.20851/j.ctt1sq5wjr

4. Friend C. Ethics in the Writing Classroom: A Nondistributive Approach. College English. Sep. 1994. Vol. 56. No. 5. P. 548-567.

5. Hevings M. Grammar for CAE and Proficiency with answers. Cambridge University Press. 2009. 296 p.

6. Knoblauch C. H. Critical Teaching and Dominant Culture. Composition and Resistance. Ed. C. Mark Hurlbert and Michael Blitz. Portsmouth. NH : Boynton/Cook. 1990. P. 12-24.

7. Stotsky S. Conceptualizing Writing as Moral and Civic Thinking. College English. Nov. 1992. Vol. 54. No. 7. P. 794-808.

8. Stotsky S. Academic Guidelines for Selecting Multiethnic and Multicultural Literature. The English Journal. Feb. 1994. Vol. 83, No. 2. P. 27-34.

9. Swales J. \& Feak C. Academic Writing for Graduate Students: A Course for Nonnative Speakers of English. Ann Arbor : The University of Michigan Press. 2005. 


\section{ДУжик Н. С. ЗАСТОСУВАННЯ ЕТИЧНОГО ПІДХОДУ \\ ДО РОЗВИТКУ ПИСЬМОВОГО МОВЛЕННЯ У ВИЩІЙ ШКОЛІ}

У статті досліджуються теоретичні основи розвитку письмового мовлення у вищій школі з етичного погляду. Особлива увага приділяється моделі Стоцької (Stotsky). Завдяки своїй смисловій вагомості модель може застосовуватися у вивченні основ академічного письма та розвитку етичного мислення. Теоретичне значення підходу полягає в кониептуалізації обов'язків автора, які виокремлені в чотири категорії і представляють створення текстів як різнобічний інтелектуальний процес за участю автора, інших авторів та читачів. Втілення ідеї академічної доброчесності та розгляд переконливих аргументів проти плагіату уможливить формування у студентів поваги до академічної праиі та допоможе їм уникнути етичних проблем зі створенням текстів. Ця модель не враховує соиіальних та культурних вимірів комунікації та трунтується на фундаментальних академічних стандартах. На прикладах показано, як розвивати письмове мовлення відповідно до етичного підходу.

Разом із традииійними настановами у статті представлені новітні підходи до викладання англійської мови, зумовлені глобалізачією та технологічним прогресом. Теперішня молодь повсякденно використовує ицфрові технології та активно обмінюється інформацією в соиіальних мережах, в яких порушення етичних норм-звична річ. Саме тому переосмислення традиційних методів та обговорення нових тенденцій здійснюється з огляду на иифрове середовище.

Відстежуючи сучасні тендениії, що полягають в інтеграчії соџіально-вагомих питань у зміст курсів, стаття акиентує на методологї̈, застосовної до українських університетів. Хоча українське студентство загалом є однорідним у культурному плані, питання багатокультурності має бути включене до освітніх програм з огляду на збільщення кількості іноземних студентів та потребу у сприянні міжкультурному обміну.

Порівняно з багатокультурністю, питання соціальної справедливості та участі в громадському житті належним чином представлені в зарубіжних англомовних джерелах. Останні є гарним прикладом для моделювання завдань, що трунтуються на украӥнських реаліях. У статті наведено приклад такого завдання.

Ключові слова: розвиток письмового мовлення, навчання англійської мови, етичний підхід, плагіат, інклюзивність. 